\title{
Financial Market Integration: Empirical Evidence from the COMESA
}

\author{
Aklilu Gebrehiwot \\ Alliant International University, D.B.A/Finance Candidate \\ E-mail: agebrehiwot@alliant.edu \\ Mustafa Sayim \\ Alliant International University, D.B.A/Finance Faculty \\ E-mail: msayim2@alliant.edu
}

Received: October 12, 2015 Accepted: October 25, 2015

doi:10.5296/ber.v5i2.8416 URL: http://dx.doi.org/10.5296/ber.v5i2.8416

\begin{abstract}
The purpose of this research paper is to investigate the level of financial market integration in the COMESA (The Common Market for Eastern and Southern Africa) regional market over the period from January 2005 to December 2013 using monthly data. Due to data constraint, we select ten countries from the COMESA regional market that have relatively stable data. We also include two big international markets - China and the U.S. to assess the level of integration of the regional market with two of the key global market leaders. To analyze the long-run relationship among the markets, we use the Level-VAR procedure that was proposed by Toda and Yamamato (1995).

Despite the establishment of NEPAD (The New Partnership for Africa's Development) to promote free trade zone and regional integration, and the advent of structural adjustments, we find that the level of financial market integration in the COMESA regional market is not significant, and most of the markets are still fragmented. The financial market integration of the regional market (COMESA) with the two big international markets - China and the U.S. is not also significant to realize integration with the global market leaders.
\end{abstract}

Keywords: COMESA, NEPAD, Market Integration, VAR Procedure

\section{Introduction}

The idea of global and regional economic integration has become a strategic tool for a 
number of countries, and governments around the world. Several countries have established a number of regional and global trade partnership zones with the objective of enhancing trade and capital flows across their borders. COMESA ${ }^{1}$ (The Common Market for Eastern and Southern Africa) is one of the few regional markets in Africa which was established by the eastern and southern African countries in December 1994, officially replaced the former preferential Trade Area (PTA) which had been in place since 1981. The formation of COMESA as a regional market was launched with the objective of economic prosperity through regional integration. COMESA has 19 member countries with an estimated population of over 389 million. Recently, the COMESA market import and export bills hit above $\$ 32$ billion, and $\$ 82$ billion respectively (COMESA database, 2015).

In an effort to establish a free trade zone among African countries, Africans have been taking a number of credible steps for decades, and by the year 2001, they were able to establish a new developmental partnership among African countries. This new partnership agreement $(\mathrm{NEPAD})^{2}$ was established by African countries with the objective of ensuring market integration through the creation of free trade zones (African Development Bank Group, 2010). As a result, Several African countries have taken decisive actions on key integration pillars, such as the reduction/removal of intra-regional tariffs, infrastructure development, etc. However, the measures taken so far are not enough to materialize the full benefit of a regional integration and still, a comprehensive effort is required to achieve their dream of becoming integrated states.

The financial market of COMESA member countries is mostly dominated by government run banks and the contribution of private banks to the development of the financial market is very limited. The lack of transparency and unease banking procedures discourage users from getting loans. Insurance companies in the COMESA region are also small and incapable to support the development of the financial market. The securities market in the region is at its early stage and there are only few countries so far have introduced market securities in their financial system (African Development Bank Group, 2010).

To tackle the bottlenecks of the banking system, COMESA members and other African countries have undergone significant reforms over the past decade. As a result, many African countries have opened their door for domestic and foreign investors who would like to invest in the banking industry. While the magnitude of reform and subsequent outcome differ across countries, the banking system in most countries have shown tremendous change in key areas, such as transparency, accessibility to loan/credit, entry for foreign investors, ease regulations, increased bank privatization, and so on. The opening up of the banking sector to foreign investors called for locally owned banks to take further action in order to survive competition. Notwithstanding to the progress COMESA member countries have shown to change their

\footnotetext{
${ }^{1}$ COMESA refers to the common market of Eastern and Southern Africa countries. The COMESA member countries include: Angola, Burundi, Comoros, Democratic Republic of Congo, Djibouti, Egypt, Eritrea, Ethiopia, Kenya, Libya, Madagascar, Malawi, Mauritius, Namibia, Rwanda, Seychelles, Sudan, Swaziland, Uganda, Zambia, and Zimbabwe.

2 The New Partnership for Africa's Development (NEPAD) is an economic development program of the African Union. NEPAD aims to provide an overarching vision and policy framework for accelerating economic co-operation and integration among African countries, established in 2001.
} 
financial institutions, the financial market development of the COMESA market (including the banking sector) is at its early stage to ensure financial integration in the region.

This study uses VAR procedure to examine the financial market integration among the COMESA member countries. First, we calculated interest rate differentials for both interest rates - the bank prime lending rate, and treasury bills, and then we applied Level-VAR procedure, including the Granger Causality test and Variance Decomposition (VDC) technique to examine the long-run relationship among the COMESA member countries.

The rest of the paper is organized as follows: Section 2 covers literature review, Section 3 discusses data and descriptive statistics (unit roots test is also included), Section 4 presents Granger Causality test, Section 5 contains Variance Decomposition analysis (VDC), and Section 6 presents conclusion of the research paper.

\section{Literature Review}

The pervasiveness of global and regional economic integration, and the opportunities ensured through market integration have attracted the attention of not only governments and institutions, but also researchers and scholars in the fields of finance and economics. As economic integration is a multi-facet and relatively new concept, the indices examined and the methods used by researchers are quite different. However, most of the studies we can find share one important concept, the Law of One Price (LOP) ${ }^{3}$, which is one of the widely recognized principles of an economic integration. It is a theory that the price of a given security, commodity or asset will have the same price when exchange rates are taken into consideration.

As arbitrage becomes the basic drive for market integration and price convergence, the effectiveness of market integration is assessed by the relative price convergence of integrated markets. As a result, integrated markets have shown efficiency due to the effects of technology and spillovers in an integrated market.

The number of empirical studies on financial market integration has grown alarmingly in the last two decades; a lot of experimental studies have been done on various methods and price indices. For example, Adam et al (2002) employ popular economic indicators from cross-country growth regressions of economic growth, such as $\beta$-convergence and $\sigma$-convergence, others such as Kleimeier and Sander (2000) examine financial market integrations among markets using cointegration analysis, Flood and Rose (2005) propose the inter-temporal asset-pricing model to measure the financial integration of countries, etc.

Despite a sizeable number of studies exist, the focus of most of the studies have been on developed countries where in their financial market is fully developed. The number of studies that investigate the financial market integration of Africa and its regional markets are not only few in number, but they are also limited in scope. The focal point of most of the studies that have been carried out in the continent, lean towards the investigation of stock market

\footnotetext{
${ }^{3}$ The low of one price (LOP) is an economic theory which states the price of a given security, commodity, or asset will have the same price when exchange rates are taken into consideration. The law of one price is another way of stating the concept of purchasing power parity.
} 
integration, and market return and efficiency.

The findings of most of the studies indicate the continent's stock market is not fully developed to realize the benefits of regional integration, and they are still fragmented. For example, Sam Agyei-Ampomah (2011) who examines the stock market integration of the continent finds not only insignificant integration among the continent's stock market industries, but also insignificant and fragmented correlation between the continent's stock market and the global stock market. Other studies that have made focus on the continent's stock market also find similar result (e.g. Ncube and Mingiri, 2015; Yabaral, 2012; Alagidede, 2008). In addition, other studies which investigate the continent's market return and efficiency conclude the continent's markets are inefficient and their return is significantly low, compare to the financial markets of developed nations (e.g. Graham and Smith, 2006; Appiah-Kusi and Menya, 2003; Magnusson and Wydick, 2002).

The purpose of our research paper is not to assess the stock market integration of the COMESA member countries, but it's designed to investigate the financial integration of these markets from a different perspective. Instead of using stock market indicators as it has been common to several studies that have been conducted in the continent, we prefer to use the banking sector indicators, such as the bank's prime lending rate, and treasury bills to examine the level of financial integration among the COMESA member countries.

To investigate the level of integration among the COMESA member countries, the paper will identify and measure the interest rate convergence of the member countries using the VAR analysis procedure. The financial market convergence is expected to hold true if the conditions of interest rate parity (IP) is satisfied. Hence, the COMESA member countries' lending rates and their treasury bills are expected to converge through time due to the effects of integration. Specifically, the paper will use the VAR procedure including the Granger causality test, and variance decomposition to find out the level of integration in the regional market.

We believe that the impact of financial integration has not been fully studied in developing countries, especially in the African continent, and this research paper will contribute to the existing literatures by providing new insights and evidence to the issue of financial market integration in the continent.

\section{Data and Methodology}

Our study uses monthly data of the bank lending rates and government treasury bills for the period from January 2005 to December 2013 for 12 selected COMESA countries. The countries include: Kenya(KEN), Egypt(EGY), Madagascar(MDG), Mauritius(MUS), Malawi(MWI), Rwanda(RWA), Swaziland(SWZ), Seychelles(SYC), Uganda(UGA), Zambia(ZMB), and the other two big international markets are the U.S and China(CHN) markets. Due to lack of reliable data, we excluded another twelve member countries from our study. The countries that are included in our study are considered to be stable and relatively have big market economy, and we believe, the outcome of the study will reflect the characteristics of those countries not represented in our study. Besides, we use Kenya as a 
cross-reference for the whole COMESA market for having a stable economy as compare to the other regional countries (Kenya market is used as a standard for comparison in most empirical investigations throughout the paper). ${ }^{4}$ The data of the research paper was retrieved from the International Financial Statistics (IFS) Database (July, 2015).

For the purpose of comparison, interest rates are recalculated after they are converted in to US dollar equivalence. However, in the absence of adequate data series, market interest rates can be used a proxy for the bank lending rates. In this case, we use market interest rates as a proxy for the bank lending rates of China and Rwanda. In total, 1440 observations are used for each interest rate category - the bank lending rate, and treasury bills.

Finally, we incorporate two external big markets, the U.S and China, in our analysis. The U.S and China are trade partners with the COMESA member countries and their inclusion can help compare the financial market integration of the COMESA countries beyond their borders. We use a VAR procedure, including the Granger causality test, Level VAR analysis, and the Variance Decomposition technique to examine the long-run relationship among the COMESA member countries.

\subsection{Panel Unit Root Tests}

A panel unit root test is a multivariate regression technique which is comprised of multi-unit root tests including the Augmented Dickey-Fuller (ADF), Phillips-Perron (PP) and Kwiatkowski, Phillips, Schmidt and Shin (KPSS) tests. For this paper, we used panel unit root tests namely, Levin, Lin and Chu (2002), Im', Pesaran and Shin (2003) and the well-known augmented Dikey-Fuller (ADF) and Phillips-Perron (PP) unit root tests in the heterogeneous panel data. It's customary to conduct a unit root test to check the stationary property of the data before any further data analyses is performed.

Table 1-A and 1-B present summary of the unit root test for lending rates and treasury bills of the countries involved in the study.

\section{Panel Unit Root Test}

Table 1-A

\begin{tabular}{|l|c|c|c|c|}
\hline A. Lending Rates & \multicolumn{2}{|c|}{ Level Series } & \multicolumn{2}{c|}{ First - Differenced } \\
\hline Method & Statistics & P-Value & Statistics & P-Value \\
\hline Levin, Lin \& Chu t* & -0.4428 & 0.3290 & -17.1841 & 0.0000 \\
\hline Im, Pesaran and Shin W-stat & 0.5319 & 0.7026 & -17.4436 & 0.0000 \\
\hline ADF - Fisher Chi-square & 33.1217 & 0.1015 & 334.5850 & 0.0000 \\
\hline PP - Fisher Chi-square & 42.7233 & 0.0107 & 527.7320 & 0.0000 \\
\hline
\end{tabular}

\footnotetext{
${ }^{4}$ The data of bank lending rates and treasury bills was retrieved from the International Financial Statistics (IFS) Database (July, 2015) for the following countries: Kenya, Egypt, Madagascar, Mauritius, Malawi, Rwanda, Swaziland, Seychelles, Uganda, Zambia, Rwanda, China, and the U.S. In the absence of adequate monthly data series of lending rates for China and Rwanda, we use the market interest rate as a proxy, retrieved from the International Financial Statistics (IFS) Database (July, 2015)
} 
Table 1-B

\begin{tabular}{|l|c|c|c|c|}
\hline B. Treasury Bills & \multicolumn{2}{|c|}{ Level Series } & \multicolumn{2}{c|}{ First - Differenced } \\
\hline Method & Statistics & P-Value & Statistics & P-Value \\
\hline Levin, Lin \& Chu t* & -0.8684 & 0.1926 & -11.9030 & 0.0000 \\
\hline Im', Pesaran and Shin W-stat & -2.8942 & 0.0019 & -17.4118 & 0.0000 \\
\hline ADF - Fisher Chi-square & 44.1221 & 0.0074 & 341.7630 & 0.0000 \\
\hline PP - Fisher Chi-square & 30.0896 & 0.1818 & 526.2240 & 0.0000 \\
\hline
\end{tabular}

The panel unit root test shows that the bank's lending rates, and treasury bills are not stationary at levels, but they are stationary at the first differenced price series for all 12 markets. The non-stationary property of the series at levels, and the stationary behavior of the series at first difference indicate the bank's lending rates, and treasury bills are integrated of order I(1).

\section{Granger Causality Test and VAR Analysis}

The short-run relationship between markets can be specified by using the Granger Multivariate Causality test (Granger 1969). According to Granger, a market index can cause another market index, only when past values of the first index explains the second, but past values of the second fails to explain the first. If both first and second indexes are found cointegrated, Granger proposes to conduct the causality test using the ECM criteria. The Granger Causality test conditioned Error Correction Model (ECM) for cointegration is given by:

$$
\Delta Y=\gamma_{o}+\sum_{i=1}^{r} \Psi \Theta_{\mathrm{t}-1}+\sum_{\mathrm{i}=1}^{\mathrm{m}} \gamma_{\mathrm{i}} \Delta \mathrm{Y}_{\mathrm{t}-1}+\varepsilon_{\mathrm{t}}
$$

Where, $\Theta$ contains $r$ individual error correction terms, $r$ is the long-term cointegrating

Vector via Johansen procedure, $\psi$ and $\gamma$ are parameters to be estimated, all other variables are as previously defined.

The error correction model (ECM) requires the order of co-integration for better results. The co-integration order can be obtained using the trace test which was developed by Johansen (1991) and Johansen and Juelius (1990). For example, the null hypothesis of $\mathrm{H}_{0}: r=0$ shows the non-co-integration relationship, while the alternative hypothesis $\mathrm{H}_{1}: \mathrm{r}>0$ shows the co-integration relationship.

In order to carry out the trace test statistics, the optimal lag order should be determined, the lag order can be determined using both the likelihood ratio test and information criteria in a VAR model. For this paper, the likelihood ratio test is used to determine the optimal number of lags and is represented by:

$$
L R=(T-K) \ln \left(\left|\Sigma_{o}\right| /\left|\Sigma_{A}\right|\right)
$$


Where, $T=$ number of observations, $K=$ number of restrictions, $\varepsilon$ denotes the covariance matrix of the error term, and subscripts 0 and $A$ represent the restricted and unrestricted VAR respectively. The null hypothesis for the number of lags is tested using equation (3) and is equal to $\mathrm{K}-1$, while the alternative hypotheses take $\mathrm{K}=2,3, \ldots, \mathrm{Kn}$. The process continues until the null hypothesis fails to be rejected, and the optimal lag which corresponds to the lag of the null hypothesis is selected.

The problem associated with Granger Causality test is that it's affected by the specification of the model. ECM model is also affected by the number of lags and co-integration equations derived from the pre-test unit root and Johansen (1991) Co-integration tests. Toda and Yamamoto (1995) propose the level VAR procedure to correct any possible pre-test unit root bias. The estimated VAR model is represented by:

$$
Y_{t=} \hat{y}_{o}+\hat{y}_{1} t+\cdots+\hat{y}_{q} t^{q}+\hat{\mathrm{J}}_{1 y t-1}+\cdots+\hat{\mathrm{J}}_{k y t-k}+\hat{\mathrm{J}}_{p y t-p}+\hat{\varepsilon}_{t}
$$

Where, $\mathrm{t}=1, \mathrm{~T}$ is the trend term and $\hat{y}_{i}, \mathrm{~J}_{i}^{\wedge}$ are parameters to be estimated by OLS

The common practice in VAR models is to check the stationary properties of variables before running the model. However, the conversion of data into first difference comes with the risk of losing the long -run properties of the variables that are under investigation (Sims, 1980; stock and Watson, 2001).

For this research paper, we decide to use all variables at level when estimating the long-run relationship between the variables. Hence, we follow the "Level VAR" estimation technique proposed by Toda and Yamamato (1995). The Granger causal relationship between COMESA member countries is presented below:

Table 2 shows the causal relationship between COMESA member countries. Taking bank lending rates as a factor, we find a total of 32 causal linkages between COMESA member countries. Countries such as Swaziland and Seychelles Granger cause five different markets in the region, while Madagascar Granger causes four markets in the region. On the other hand, Kenya, Egypt, Rwanda and Mauritius, each of them are Granger caused by three different markets. Among others, Seychelles is Granger caused by six markets in the region. It also indicates China and the US, each granger cause three markets in the region. We also find that there is a bidirectional relationship between the following markets: Seychelles vs. Swaziland, Uganda vs. Kenya, Uganda vs. Egypt, China vs. the U.S., China vs. Seychelles; China vs. Rwanda, and US vs. Mauritius. 


\section{Macrothink}

Table 2. Long -run Causality Test by Level - VAR

$\underline{\text { Lending rates }}$

\begin{tabular}{|c|c|c|c|c|c|c|c|c|c|c|c|c|c|}
\hline & KEN & CHN & EGY & MDG & MUS & MWI & RWA & SWZ & SYC & UGA & USA & ZMB & Caused \\
\hline KEN & & 0.124 & $0.075^{*}$ & 0.767 & 0.900 & 0.117 & 0.445 & 0.110 & 0.075 & $0.020^{* *}$ & 0.266 & 0.539 & 2 \\
\hline $\mathrm{CHN}$ & 0.705 & & 0.278 & 0.950 & $0.001 * * *$ & 0.525 & $0.015 * * *$ & 0.346 & $0.000 * * *$ & $0.075^{*}$ & $0.001 * * *$ & 0.224 & 5 \\
\hline EGY & 0.574 & 0.199 & & 0.198 & 0.157 & 0.686 & 0.271 & 0.778 & 0.191 & 0.742 & 0.174 & 0.370 & 0 \\
\hline MDG & 0.770 & 0.911 & $0.0262 * *$ & & 0.859 & 0.213 & $0.000^{* * * *}$ & 0.940 & $0.009 * * *$ & 0.708 & $0.018 * * *$ & 0.993 & 4 \\
\hline MUS & 0.218 & 0.185 & 0.270 & 0.550 & & 0.391 & 0.353 & 0.449 & $0.000 * * *$ & 0.654 & $0.000 * * *$ & $0.089^{*}$ & 3 \\
\hline MWI & 0.365 & 0.695 & $0.004 * * *$ & 0.376 & 0.308 & & 0.766 & 0.777 & $0.015^{* * *} *$ & 0.977 & 0.165 & 0.119 & 2 \\
\hline RWA & 0.920 & $0.068 * *$ & 0.495 & 0.400 & 0.440 & 0.657 & & 0.955 & 0.799 & 0.856 & 0.322 & 0.451 & 1 \\
\hline SWZ & $0.025 * *$ & $0.000 * * *$ & 0.475 & 0.998 & 0.461 & 0.455 & 0.327 & & $0.000 * * *$ & 0.342 & $0.004 * * *$ & $0.097 *$ & 5 \\
\hline SYC & 0.035 & $0.000 * *$ & 0.780 & 0.555 & $0.052 * *$ & 0.542 & $0.053^{* *}$ & $0.031 * *$ & & 0.463 & 0.389 & 0.428 & 5 \\
\hline UGA & $0.000 * * *$ & 0.485 & 0.754 & 0.295 & 0.445 & 0.813 & 0.274 & 0.156 & 0.635 & & 0.199 & 0.508 & 1 \\
\hline USA & 0.116 & $0.013 * * *$ & 0.452 & 0.517 & $0.016^{* * * *}$ & 0.333 & 0.704 & 0.800 & $0.002 * * *$ & 0.305 & & 0.036 & 3 \\
\hline ZMB & 0.790 & 0.880 & 0.935 & 0.182 & 0.634 & 0.227 & 0.636 & 0.498 & 0.494 & 0.917 & $0.002 * * *$ & & 1 \\
\hline $\begin{array}{l}\text { Be } \\
\text { caused }\end{array}$ & 3 & 4 & 3 & 0 & 3 & 0 & 3 & 1 & 6 & 2 & 5 & 2 & 32 \\
\hline $\begin{array}{l}\text { Note } \\
\text { rows" } \\
\text { Kenya } \\
\text { count1 }\end{array}$ & $\mathrm{KEN})$ & y col & n" sh & S V & $n$ a c & 1 & ang & acsos & 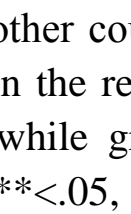 & . & $\begin{array}{l}\text { aused } \\
\text { J. }\end{array}$ & "col & $\begin{array}{l}\text { n by } \\
\text { nple, } \\
\text { two }\end{array}$ \\
\hline
\end{tabular}

Taking treasury bills as a factor (table 3), we find a total of 41 causal linkages among the markets that are selected for investigation. From the same time, we find Swaziland ganger causes a total of six markets, five regional markets and one international market (China), where as the Swaziland market is granger caused by two international markets (China, and the U.S.) and one regional market (Madagascar). Zambia granger causes five markets, but it's granger caused by two markets in the region. Countries, such as Mauritius, Malawi, and Uganda granger cause three markets each, while they are granger caused by other three markets in the region with the exception of Malawi which is granger caused by six markets in the region. In regard to China and the US, we find China granger causes four regional markets, but it's caused by three regional markets and one international market (the U.S.). In contrast, the US granger causes three regional markets and one international market (China), while it's caused by two regional markets.

We also find there is a bidirectional relationship between the following countries: China vs. Zambia, China vs. Swaziland, and the U.S. vs. Seychelles.

The following table (3) shows the casual relationship between COMESA member countries, taking treasury bills as factor. 


\section{MInstitute Macrink $_{\text {ins }}$}

Table 3. Long -run Causality Test by Level - VAR

$\underline{\text { Treasury Bills }}$

\begin{tabular}{|l|l|l|l|l|l|l|l|l|l|l|l|l|l|}
\hline & KEN & CHN & EGY & MDG & MUS & MWI & RWA & SWZ & SYC & UGA & USA & ZMB & Caused \\
\hline KEN & & 0.531 & 0.716 & 0.716 & 0.595 & 0.303 & 0.256 & 0.987 & 0.617 & 0.124 & $0.027^{* *}$ & 0.524 & 1 \\
\hline CHN & 0.981 & & 0.684 & 0.684 & 0.569 & $0.004 * * *$ & 0.829 & $0.005^{* * *}$ & $0.020^{* *}$ & 0.972 & 0.368 & $0.000^{* * *}$ & 4 \\
\hline EGY & 0.206 & 0.777 & & 0.248 & 0.691 & $0.000^{* * *}$ & 0.527 & 0.618 & 0.226 & $0.015^{* * *}$ & 0.423 & 0.331 & 2 \\
\hline MDG & 0.503 & $0.000^{* * *}$ & 0.248 & & $0.069 *$ & 0.458 & 0.958 & $0.009 * * *$ & $0.043^{* *}$ & 0.356 & 0.745 & $0.000^{* * *}$ & 5 \\
\hline MUS & 0.979 & 0.229 & $0.01 * * *$ & $0.01 * * *$ & & $0.004^{* * *}$ & 0.548 & 0.328 & 0.537 & 0.888 & 0.361 & 0.791 & 3 \\
\hline MWI & 0.640 & 0.304 & $0.060^{*}$ & $0.060^{*}$ & 0.764 & & 0.591 & 0.456 & 0.277 & $0.003^{* * *}$ & 0.235 & 0.131 & 3 \\
\hline RWA & 0.711 & 0.368 & 0.123 & 0.123 & 0.202 & $0.071^{*}$ & & 0.047 & $0.109^{*}$ & 0.428 & 0.195 & 0.435 & 2 \\
\hline SWZ & 0.432 & $0.015 * *$ & $0.015^{* * *}$ & $0.015^{* * *}$ & $0.063 *$ & 0.140 & 0.736 & & $0.002^{* * *}$ & $0.000^{* * *}$ & 0.603 & 0.147 & 6 \\
\hline SYC & 0.242 & 0.955 & 0.517 & 0.517 & $0.023 * *$ & $0.031^{* *}$ & 0.867 & 0.701 & & 0.169 & $0.003^{* * *}$ & 0.361 & 3 \\
\hline UGA & $0.000^{* * *}$ & 0.517 & $0.009^{* * *}$ & $0.009 * * *$ & 0.276 & 0.522 & 0.998 & 0.912 & 0.646 & & 0.688 & 0.807 & 3 \\
\hline USA & 0.738 & $0.012^{* * *}$ & 0.844 & 0.844 & 0.612 & $0.000^{* * *}$ & 0.918 & $0.071 *$ & $0.003 * * *$ & 0.771 & & 0.490 & 4 \\
\hline ZMB & $0.008^{* * *}$ & $0.095^{*}$ & $0.079 *$ & $0.079 *$ & 0.281 & 0.552 & 0.525 & 0.216 & $0.086^{* *}$ & 0.430 & 0.385 & \\
\hline Be caused & 2 & 4 & 5 & 5 & 3 & 6 & 0 & 3 & 6 & 3 & 2 & 2 \\
\hline
\end{tabular}

Note that "row by column" shows when a country's market granger causes other markets, where as "column by rows" shows when a country's market is granger caused by other markets. For example, Kenya (KEN) granger causes only one market (the U.S.), while granger caused by two other regional markets (Uganda and Zambia). Key for the P-value: $* * *<0.01, * *<.05$, and $*<.10$.

A granger causality test indicates the granger cause of one market over another market, but it does not show whether yet other regional or international market has an indirect influence over the market of interest. Therefore, we need to use the variance decomposition technique (VDC) to account the effects of the indirect influence that comes from other regional or international markets. The VDC technique detects the indirect relationship of markets by decomposing the random variation of one market into its components, and this can show the shocks that come from other markets that have a direct or indirect relationship. The decomposition process divides the forecasted market variance error into percentages such that the innovations of the market of interest, and the indirect influence that comes from other markets will clearly be identified and accounted.

The problem which is associated with VDC is the model's requirement to have the right order of variables that are to be tested. If the model is run with the wrong order of variables, the outcome of the model will be spurious and biased. Enders (2004) suggests that the existence of large correlations among variables can substantially distort the results of IRF and VDC in a VAR model. For this paper, the issue of ordering of variables is not a major concern at least for two reasons. First, the correlation between the variables that are represented in the model is significantly small, and the cause and effect relationship between these variables is expected to be small. Secondly, we ordered the variables (markets) based on the number of their cause and effect over other variables (markets). The number of cause and effect by 
markets is derived from the results of our Level VAR model.

The Level VAR model as proposed by Eun and Shim (1989) is represented by:

$$
y_{t=} \alpha+\sum_{s=1}^{n} A(S) y_{t s}+e_{t}
$$

Where, $y_{t}$ refers to a $\mathrm{mX} 1$ vector of indices, $\alpha$ and $\mathrm{A}(\mathrm{S})$ are coefficients of $\mathrm{mx} 1$, and $\mathrm{mxm}$ respectively, $\mathrm{n}$ refers to a lag length, $e_{t}$ is a forecast error term.

The granger causality test shows the direct causal relationship between variables, however, it does not clearly show the indirect relationship that may exist between the variables. In order to address this issue, we need to decompose the forecasted error variance of each market for a certain consecutive period of time (for this paper, 10 years period of time is used). Each row contains the percentage of forecasted error variance explained by the market indicated in the column. For example, the Kenyan market variance explained by its own innovation falls down from $100 \%$ in period 1 to $60.3 \%$ in period 10 . This suggests Kenyan market variance is started to be explained by the innovations of other regional and international markets.

When we look at Egypt's market, 55.6\% of its market variance is explained by its own innovations in the last period (year 10), while the remaining $44.4 \%$ of its market variance is explained by the innovations of other related regional and international markets in the same period. Seychelles's market variance own innovation is dropped from $100 \%$ (in the first period) to $19.34 \%$ in the last period (year 10), Swaziland market variance own innovation dropped from $100 \%$ in the first period to $55.8 \%$ in the last period (year 10). Many other COMESA markets have also shown similar trends in their market variance.

The ever increasing influence of China over COMESA countries makes individual market's own innovation share to fall down in recent years. For example, the Seychelles market variance which is explained by its own innovation is declined from $79.1 \%$ in period 2 to $19.34 \%$ in period 10 because of China's market influence over the Seychelles market (China's innovation share raised from $2.2 \%$ in period 2 to $7.2 \%$ in period 10). But, the influence of the U.S. market on Seychelles market is increased by few percentages, from $0.25 \%$ in period 2 to $0.53 \%$ in period 10 .

The VDC table shows the influence of China over the COMESA member countries has increased over the years.

${ }^{5}$ Table 4-A, 4-B, and 4-C present VDC of the lending rates of the COMESA member countries.

\section{$\underline{\text { VDC Table: Lending rates }}$}

\footnotetext{
${ }^{5}$ Displaying the whole market variance output for all markets is not manageable due to large space requirement and we prefer to show the output of some countries in this research paper. The variance Decomposition output of all COMESA member countries can be forwarded upon request.
} 
Table 4-A. Variance Decomposition of Kenya (For period 1, 2, 5 and 10)

\begin{tabular}{|c|c|c|c|c|c|c|c|c|c|c|c|c|c|}
\hline PERIOD & S.E. & EGY & KEN & CHN & MDG & MUS & MWI & RWA & SWZ & SYC & UGA & USA & ZMB \\
\hline 1 & 0.012 & 100 & 0 & 0 & 0 & 0 & 0 & 0 & 0 & 0 & 0 & 0 & 0 \\
\hline 2 & 0.015 & 96.286 & 0.256 & 0.134 & 1.395 & 0.513 & 1.128 & 0.180 & 0.059 & 0.000 & 0.028 & 0.020 & 0.001 \\
\hline 5 & 0.022 & 78.842 & 2.340 & 1.452 & 5.429 & 1.858 & 9.173 & 0.209 & 0.203 & 0.027 & 0.367 & 0.089 & 0.011 \\
\hline 10 & 0.029 & 55.639 & 5.037 & 5.861 & 6.227 & 2.823 & 21.658 & 0.132 & 0.444 & 0.174 & 1.843 & 0.140 & 0.020 \\
\hline
\end{tabular}

Table 4-B. Variance Decomposition of Egypt (For period 1, 2, 5 and 10)

\begin{tabular}{|c|c|c|c|c|c|c|c|c|c|c|c|c|c|}
\hline PERIOD & S.E. & EGY & KEN & CHN & MDG & MUS & MWI & RWA & SWZ & SYC & UGA & USA & ZMB \\
\hline 1 & 0.012 & 100 & 0 & 0 & 0 & 0 & 0 & 0 & 0 & 0 & 0 & 0 & 0 \\
\hline 2 & 0.015 & 96.286 & 0.256 & 0.134 & 1.395 & 0.513 & 1.128 & 0.180 & 0.059 & 0.000 & 0.028 & 0.020 & 0.001 \\
\hline 5 & 0.022 & 78.842 & 2.340 & 1.452 & 5.429 & 1.858 & 9.173 & 0.209 & 0.203 & 0.027 & 0.367 & 0.089 & 0.011 \\
\hline 10 & 0.029 & 55.639 & 5.037 & 5.861 & 6.227 & 2.823 & 21.658 & 0.132 & 0.444 & 0.174 & 1.843 & 0.140 & 0.020 \\
\hline
\end{tabular}

Table 4-C. Variance Decomposition of Seychelles (For period 1, 2, 5 and 10)

\begin{tabular}{|c|c|c|c|c|c|c|c|c|c|c|c|c|c|}
\hline PERIOD & S.E. & SYC & KEN & CHN & EGY & MDG & MUS & MWI & RWA & SWZ & UGA & USA & ZMB \\
\hline 1 & 0.094 & 100 & 0 & 0 & 0 & 0 & 0 & 0 & 0 & 0 & 0 & 0 & 0 \\
\hline 2 & 0.133 & 79.114 & 2.260 & 2.231 & 0.019 & 2.495 & 4.930 & 0.759 & 0.064 & 7.784 & 0.037 & 0.251 & 0.057 \\
\hline 5 & 0.231 & 34.402 & 14.948 & 8.924 & 0.249 & 2.784 & 4.515 & 1.860 & 0.510 & 31.049 & 0.147 & 0.510 & 0.101 \\
\hline 10 & 0.310 & 19.349 & 22.107 & 7.246 & 2.158 & 1.738 & 8.734 & 1.242 & 0.466 & 35.900 & 0.411 & 0.535 & 0.114 \\
\hline
\end{tabular}

Taking treasury bills as a factor, Kenya market variance which is explained by its own innovation dropped from $100 \%$ in period 1 to $28.7 \%$ in period 10 . This suggests the remaining $71.3 \%$ was started to be explained by the innovation of other regional and international markets. Swaziland's own innovation market variance is also dropped from $100 \%$ in period 1 to $60.1 \%$ in period 10 . Seychelles market variance which is explained by its own innovation dropped from $100 \%$ in period 1 to $35.7 \%$ in period 10 . The contribution of China's own innovation to the regional markets has been increasing over the years. For example, China's contribution to Kenya's market has increased from $0.0 \%$ (in period 1) to $3.7 \%$ in period 10, China's contribution to Swaziland and Egypt has increased by $2.2 \%$ and $1 \%$ through the 10 periods respectively.

Table 5-A, 5-B, and 5-C present VDC of the treasury bills of the COMESA member countries.

Table 5-A. Variance Decomposition of Kenya (For period 1, 2, 5, and 10)

\begin{tabular}{|c|c|c|c|c|c|c|c|c|c|c|c|c|c|}
\hline PERIOD & S.E. & KEN & CHN & EGY & MDG & MUS & MWI & RWA & SWZ & SYC & UGA & USA & ZMB \\
\hline 1 & 0.888 & 100 & 0 & 0 & 0 & 0 & 0 & 0 & 0 & 0 & 0 & 0 & 0 \\
\hline 2 & 1.150 & 93.340 & 0.112 & 0.026 & 0.000 & 0.001 & 0.124 & 0.254 & 0.050 & 0.139 & 5.537 & 0.019 & 0.397 \\
\hline 5 & 1.729 & 55.302 & 1.634 & 0.335 & 0.001 & 0.089 & 0.309 & 2.950 & 0.165 & 2.609 & 34.172 & 0.135 & 2.298 \\
\hline 10 & 2.423 & 28.708 & 3.765 & 2.278 & 0.013 & 0.345 & 0.174 & 4.542 & 0.163 & 8.401 & 48.945 & 0.289 & 2.378 \\
\hline
\end{tabular}




\section{MInstitute ${ }_{\text {Mnk }}^{\text {Macrothink }}$}

Business and Economic Research

Table 5-B. Variance Decomposition of Swaziland (For period 1, 2, 5, and 10)

\begin{tabular}{|c|c|c|c|c|c|c|c|c|c|c|c|c|c|}
\hline PERIOD & S.E. & SWZ & KEN & CHN & EGY & MDG & MUS & MWI & RWA & SYC & UGA & USA & ZMB \\
\hline 1 & 0.033 & 100 & 0 & 0 & 0 & 0 & 0 & 0 & 0 & 0 & 0 & 0 & 0 \\
\hline 2 & 0.048 & 95.366 & 0.304 & 1.159 & 0.606 & 0.150 & 0.000 & 0.148 & 0.720 & 0.929 & 0.003 & 0.480 & 0.137 \\
\hline 5 & 0.077 & 81.918 & 1.980 & 1.353 & 1.467 & 2.181 & 0.042 & 0.447 & 1.434 & 4.756 & 0.003 & 2.346 & 2.072 \\
\hline 10 & 0.103 & 60.166 & 5.262 & 0.836 & 0.985 & 10.305 & 0.240 & 0.488 & 2.505 & 7.449 & 0.237 & 4.947 & 6.581 \\
\hline
\end{tabular}

Table 5-C. Variance Decomposition of Seychelles (For period 1, 2, 5 and 10)

\begin{tabular}{|c|c|c|c|c|c|c|c|c|c|c|c|c|c|}
\hline PERIOD & S.E. & SYC & KEN & CHN & EGY & MDG & MUS & MWI & RWA & SWZ & UGA & USA & ZMB \\
\hline 1 & 0.249 & 100 & 0 & 0 & 0 & 0 & 0 & 0 & 0 & 0 & 0 & 0 & 0 \\
\hline 2 & 0.319 & 95.092 & 0.068 & 0.053 & 1.638 & 0.079 & 0.003 & 1.047 & 0.421 & 1.215 & 0.340 & 0.008 & 0.036 \\
\hline 5 & 0.448 & 61.603 & 0.185 & 0.084 & 12.477 & 0.677 & 0.077 & 9.582 & 1.211 & 11.955 & 2.061 & 0.024 & 0.063 \\
\hline 10 & 0.606 & 35.783 & 0.459 & 0.079 & 15.529 & 0.626 & 0.778 & 18.472 & 0.861 & 22.071 & 3.053 & 0.484 & 1.805 \\
\hline
\end{tabular}

\section{Conclusion}

The purpose of this research paper is to investigate the level of financial market integration among COMESA countries (The Common Market for Eastern and Southern Africa). Based on the availability of financial data, we select ten countries from COMESA members for the investigation. We also include two big international markets, such as China and the U.S. to examine the integration of the COMESA countries with the global market. We use VAR procedure (Vector Autoregression) to examine the long-run relationship among the markets of the countries that are considered for the investigation. We use monthly data, ranging from 2005 to 2013

Despite the establishment of NEPAD (The New Partnership for Africa's Development) to promote free trade zone and regional integration, and the advent of structural adjustments, we find no significant integration among the COMESA countries' financial market. The level of integration of these countries with the global market is also insignificant and fragmented. This may be due to lack of a well developed financial market, poor infrastructure, and insufficient international trade in the region

The findings, however, indicate that few regional and international markets are partially integrated in the long-run. For example, taking lending rates a factor, Seychelles has the highest long-run market integration (linked with eight markets) among COMESA member countries, followed by Swaziland (linked with five markets). When we look at the two big international markets, China and the US, we find each country is partially integrated with six COMESA member countries. However, the results of VDC indicate China's direct and indirect influence over the COMESA countries has increased overtime.

Our findings are consistent with the conclusion of the African Development Bank annual reports that were published in 2010, and later in 2014. The bank's annual report is basically prepared by its own internal research department and then officially released to the public every year. The conclusions of the bank's annual report published in 2010, and later in 2014 are similar; both reports indicate the regional integration of the COMESA member countries 
is at its early stage, and the objective of the integration is not so far achieved.

\section{References}

Adam, k., Jappelli, T., Menichini, A., Padula, M. and Pagano, M. (2002). Analyse, Compare and Apply Alternative Indicators and Monitoring Methodologies to Measure the Evolution of Capital market Integration in the European Union. Report to the EU Commission, Center for Studies in Economics and finance, University of Salerno.

Agyei-Ampomah, S. (2011). Stock Market Integration in Africa. Managerial Finance, 37(3), 242-56. http://dx.doi.org/10.1108/03074351111113306

Akdogan, H. (1995). The Intergartion of International Capital Markets: Theory and Empirical Evidence. Edward Elgar, Aldershot.

Appiah-Kusi, J., \& Menyah, K. (2003). Returns Predictability in African Stock Markets. Review of Financial Economics, 247-270. http://dx.doi.org/10.1016/S1058-3300(02)00073-3

Alagidede, P. (2008). African Stock Market Integration: Implications for Portfolio Diversification and International Risk Sharing. Proceedings of the African Economic Conferences, 1-31.

Bank, A. D. (2010-2014). Annual Report. Abidjan, Côte d'Ivoire: Department of Development Research.

Dickey, D. A., \& W. A. Fuller. (1979). Distribution of the Estimators for Autoregressive time Series with a Unit Root. Journal of the American Statistical Association, 74, 427-431.

Farid, S. (October 28-30, 2013). Financial Integration in African Emerging Markets. African Economic Conference, (pp. 1-18). Johannesburg, South Africa.

Flood, R.P. and Rose, A. (2005). A new approch to asset integration: Methodology and $\begin{array}{llll}\text { Mystery. Pacific Economic } & \text { Review, } & \text { 5-28, }\end{array}$ http://dx.doi.org/10.1111/j.1468-0106.2005.00258.x

Gail, N., \& Kapingura, M. (2015). Market Integration in Africa: The Case of the Johannesburg Stock Exchange and Selected African countries. International Business and Economics Research Journal, 14(2), 367-86.

Granger, C. (1969). Investigating Causal Relations by Econometric Models and Cross-spectral Methods. Economterica , 37(3), 424-438. http://dx.doi.org/10.2307/1912791

Im', K., Pesaran, M. and Shin, Y. (2003). Testing for Unit Root in Heterogenous Panels. Journal of Econometrics , 115(1), 53-74. http://dx.doi.org/10.1016/S0304-4076(03)00092-7

Johansen, S. A. (1990). Maximum Likelihood Estimation and Inference on cointegration With Applications to the Demand for Money. Oxford Bulletin of Economics and Statistics, 52(2), 169-210. http://dx.doi.org/10.1111/j.1468-0084.1990.mp52002003.x

Johansen, S. A. (1991). Estimation and Hypothesis Testing of Cointegration Vectors in Gaussian Vector Autoregressive Models. Econometrica, 59(6), 1551-1580. 
http://dx.doi.org/10.2307/2938278

Kleimeier, S. A. (2000). Regionalism versus Globalization in European Financial Market Integration: Evidence from Cointegration Analyses. Journal of Banking and Finance, 24, 1005-43. http://dx.doi.org/10.1016/S0378-4266(99)00116-8

Koo, J. A. (2000). Regional Income Convergence: Evidence from Panel Unit Root Tests. Seoul Journal of Economics, 13(4), 459-469.

Levin, A., Lin, C., \& Chu, C.J. (2002). Unit Root Tests in Panel Data: Asymmetric and finite-sample Properties. Journal of Econometrics, 108(1), 1-24.http://dx.doi.org/10.1016/S0304-4076(01)00098-7

Magnusson, M., \& Wydick, B. (2002). How Efficient are Africa's Emerging Stock Markets? The Journal of Development Studies, 38, 141-156. http://dx.doi.org/10.1080/00220380412331322441

Smith, G. (2008). Liquidity and the Informational Efficiency of African Stock Markets. South $\begin{array}{llll}\text { African Journal of } & \text { Economics, } & \text { 76(2), }\end{array}$ http://dx.doi.org/10.1111/j.1813-6982.2008.00171.x

Toda, H. and Yamamoto, T. (1995). Statistical Inference in Vector Autoregressions with Possibly Integrated Processes. Journal of Econometrics, 66(1-2), 225-250. http://dx.doi.org/10.1016/0304-4076(94)01616-8

Yabara, M. (2012). Capital Market Integration: Progress A head of the East African Community Monetary Union (Working Paper No. WP/12/18). IMF African Department.

\section{Copyright Disclaimer}

Copyright for this article is retained by the author(s), with first publication rights granted to the journal.

This is an open-access article distributed under the terms and conditions of the Creative Commons Attribution license (http://creativecommons.org/licenses/by/3.0/). 